\title{
PREMARITAL SEXUAL IN ADOLESCENTS AT SENIOR HIGH SCHOOL PGRI 4 BANJARMASIN
}

\author{
R. Topan Aditya Rahman', Esti Yuandari \\ \{topanaditya85@unism.ac.id\}
}

${ }^{12}$ Universitas Sari Mulia, Banjarmasin, Indonesia

\begin{abstract}
Along with its development, adolescents begin to explore with themselves, the values of identity roles and behavior. Various factors influence changes in the behavior of adolescents' lives, both internal and external factors. If this is not dealt with carefully, adolescents will be increasingly faced with unhealthy reproductive problems, such as premarital sex that have an impact on both the physical impact, the psychological impact and the psychosocial impact of the teenager. This study aims to identify sexual behavior in adolescents. This research uses qualitative methods, sampling is done by purposive sampling. The results showed that premarital sexual behavior among adolescents was caused by various backgrounds influenced by internal factors, namely lack of adolescent knowledge about sex education, and external factors such as lack of parental role in efforts to prevent premarital sexual behavior, and a shift in values and norms regarding behavior premarital sex among teenagers
\end{abstract}

Keywords : Behavior, Adolescents, Sex, Premarital 


\section{INTRODUCTION}

Teenagers are defined as a period of developmental transition from childhood to adulthood, which includes aspects of biology, cognitive, and social change that take place between the ages of 10-19 years [1]. Teenagers are high potential human resources, their awareness of reproductive health is important to grow. Teenagers, along with their development begin to explore with themselves, the values of their role identity and behavior. In the issue of sexuality, teenagers are often confused by the changes that occur in him. When adolescents enter puberty, adolescents experience rapid physical changes, and already have reproductive abilities. But precisely there are many phenomena that show some teenagers do not know and understand about their reproductive health [2].

According to a survey of the National Commission for Child Protection and the Ministry of Health in October 2013 stated that around $62.7 \%$ of adolescents in Indonesia have had sex outside marriage. 20\% of 94,270 adolescent women experience pregnancy out of wedlock, and $21 \%$ of them have had an abortion. [3]

The National Family Planning Coordinating Board (BKKBN) based on a survey stated that half the single teenage girls living in Jakarta, Bogor, Tangerang, and Bekasi lost their virginity and had premarital sex. The age range of teenagers who have had sex outside of marriage between 13-18 years. Based on data from 100 teenagers, 51 of them are no longer virgins. Besides in Jabodetabek. In Surabaya, for example, single teenage girls whose virginity had disappeared reached 54 percent, in Medan 52 percent, Bandung 47 percent, and Yogyakarta 37 percent. [4]

Investigations and surveys of the Banjarmasin "LEMPEMA" Society from 2014 to 2016 with a total of 700 respondents, it was found that $65 \%$ of girls in Banjarmasin had premarital sex. [5]

Based on preliminary study conducted by researchers of 30 students in class 2 Senior High School PGRI 4 Banjarmasin on October 10, 2018, obtained data as much as 100 percent of respondents said they had dated, 56.7\% of respondents dating more than 4 times, the age of dating first ranged between ages 13-15 years, $40 \%$ of respondents kissed their lips, embraced $33.3 \%$ of respondents, petting $16.6 \%$ of respondents. Of the 30 respondents 96.6\% said they did not agree with premarital sexual behavior, $83.3 \%$ had friends who had premarital sex, $63.3 \%$ of respondents said they had friends who were pregnant before marriage, $73.3 \%$ had watched pornographic films, and openly $23.3 \%$ of respondents had had premarital sex.

\section{METHOD}

This research is a qualitative research. To describe the phenomenon of premarital adolescent sexual behavior in depth, using a descriptive exploratory approach. [6]

The research subjects in this study were all teenagers in the city of Banjarmasin. Sampling is done by purposive sampling technique. [7] The main informants in this study were Senior High School PGRI 4 Banjarmasin students and triangulation informants namely parents. 


\section{RESULT}

\section{A. Informant Charactersitics}

1. Main Informant

The main informants consisted of 4 high school students from Banjarmasin PGRI 4 Banjarmasin class XI and class XII, namely two men and two women.

2. Triangulation Informant

Triangulation informants 3 parents of students.

\section{B. Reasearch Result}

\section{Premarital Sexual Behavior in Adolescents}

Adolescent background to engage in premarital sexual behavior because of a shift in values and norms that are considered as common and common in dating which is a proof of love for their partners, imitating what they see in electronic media in the form of pornographic videos. Premarital sexual behavior in adolescents they usually do at the home of a friend who lives alone and this is done with their girlfriends

\section{Factors Affecting Premarital Sex Behavior in Adolescents}

Internal Factor

Knowledge

Adolescents have the perception that premarital sexual behavior is a proof of love for their partners who are done on the basis of like and like. In addition, premarital sexual behavior is having sexual relations before being legalized by religion or engaging in intimate relationships which is usually done by adolescents during courtship.

\section{External Factors}

\section{1) Family Role}

Many things parents do to prevent their children from engaging in premarital sex. There are parents who curb their children and there are even parents who do not allow their children to date before college. However, there are also parents who give freedom and allow their children to go out even though they are still in high school. Parents hope that by giving freedom that is responsible and giving advice to their children can avoid premarital sexual behavior in adolescents.

\section{2) Values and Norms}

Teenagers know the values and norms that apply in society and in religion regarding premarital sexual behavior that it is an act that should not be done prematurely. However, adolescents revealed that nowadays premarital sexual behavior is normal or common among teenagers when dating. The statement 
that if they do not engage in adolescent premarital sexual behavior is considered not slang by their friends, it makes it difficult for teens to avoid this

\section{DISCUSSION}

\section{Premarital Sexual Behavior in Adolescents}

Premarital sexual behavior is defined as behavior that increases a person's risk of contracting sexually transmitted infections and having an unwanted pregnancy meant having sex at a young age, having multiple sex partners, having sex under the influence of alcohol or drugs and engaging in unsafe sexual behavior [8]. Premarital sex behavior occurs because of internal and external factors. Opening opportunities for adolescents to engage in premarital sexual behavior is also supported by a number of things, such as the lack of attention from parents towards their children. So that teens prefer to talk about reproductive health issues to their peers. Especially in adolescence, more adolescents are outside the home with their peers, and adolescents try to find their concept of life. Where adolescents will be judged by their peers regardless of the sanctions they will receive.

\section{Factor Affecting Premarital Sex Behavior in Adolescents Internal Factor (knowledge)}

Adolescent knowledge about reproductive health or sex education shows that adolescent girls tend to have low knowledge about reproductive health. The lack of adolescent knowledge about reproductive health results in adolescents having a wrong understanding of reproductive health or sex education. Premarital Sex Behavior at a young age should be a major concern for reducing high pregnancy rates and sexually transmitted diseases [9]. Knowledge is the result of knowing as a result of the sensing process of a particular object, sensing occurs mostly through vision and hearing [10]. Adolescents have the perception that premarital sexual behavior is a proof of love for their partners who are done on the basis of like and like. In addition, premarital sexual behavior is having sexual relations before being legalized by religion or engaging in intimate relationships which is usually done by adolescents during courtship. The research is in line with Rahmawati, et al (2015) which says that students who have knowledge about premarital sexual behavior also have high-risk sexual behavior. Of the 201 respondents who were well informed, there were 151 respondents $(65.2 \%)$ who had high-risk sexual behavior. [11]

\section{External Factors}

\section{1) Family Role}

The role of communication in the family is very important as a vehicle for transferring values and agents of cultural transformation. Communication can take place both vertically and horizontally between parents to their children and vice versa. Parents must have sufficient knowledge about reproductive health and sex education in order to be able to explain to their children the questions to 
the wrong sources. The effectiveness of communication can be seen through two points of view, namely the humanistic point of view and the pragmatic point of view. The humanistic perspective emphasizes openness, empathy, supportive attitude, and other qualities that create meaningful, honest, and satisfying interactions. The pragmatic point of view emphasizes management and freshness of interaction, and in general, the qualities that determine the achievement of specific goals. These two perspectives complement each other in understanding the effectiveness of communication, but for parent and child communication, a humanistic point of view is more appropriate to assess the effectiveness of interpersonal relationships because it is based on general qualities that determine the creation of superior human relationships (eg honesty, openness , and positive attitude). [12]

\section{2) Values and Norms}

Teenagers know that premarital sexual behavior is something that is prohibited both from religion and from the community itself. Adultery is taboo and illegal in the normative system of Indonesian society. However, as the times evolve, the culture of free sex is not considered taboo. Teenagers tend to follow things that are often done by their friends, for example if their friends are dating, so teenagers tend to follow that matter regardless of the consequences. Peer groups are environments where adolescents can socialize where the values that apply are not values that are applied by adults but by peers. Herein lies the danger for the development of adolescent's soul, if the value that develops in the group is negative, where each member cannot be separated from the group and must follow the values developed by the group leader, attitudes, thoughts, behavior and lifestyle are the behavior and lifestyle

of the group . Teenagers also seek more freedom from parents by spending more time with their friends. [13]

\section{CONCLUSION}

Based on the results of research on adolescent premarital sexual behavior in PGRI 4 High School Banjarmasin can be concluded as follows:

1. Premarital sex behavior that is rife in adolescents is caused due to several reasons or backgrounds. Adolescents engage in premarital sexual behavior as evidence or a sign of their affection towards their partner, the hope that their partner gives them Adolescents are often in the environment of their peers so that adolescents follow the values that exist in their peers who think that premarital sexual behavior is a common thing and is commonly done when dating.

2. Factors that cause adolescents to engage in premarital sexual behavior consist of internal and external factors, namely:

a. One internal factor that causes adolescents to engage in premarital sexual behavior is a lack of teenage knowledge about reproductive health or sex education.

b. External factors for premarital sexual behavior in adolescents include the following: 
1) The role of the family is very necessary to prevent premarital sexual behavior. Parents tend to have permissive parenting which is indulgent so adolescents are less able to exercise self-control.

2) Teenagers know that premarital sexual behavior is something that is prohibited both from religion and from the community itself. However, there is a shift in values and norms along with the times, especially among adolescents who consider that premarital sexual behavior is a normal and commonly practiced relationship as a proof of affection for their partners.

\section{ACKNOWLEDGEMENT}

The researcher would like to thank profusely the head of the Senior High School PGRI 4 in Banjarmasin who has given permission for the researchers to conduct research, not forgetting the leaders and fellow lecturers at Sari Mulia University who have given encouragement and assistance to researchers so that researchers can complete research this.

\section{REFERENCES}

[1] Tarwoto et al. Kesehatan Remaja : Problem dan Solusinya. Jakarta: Salemba Medika. (2010).

[2] Aden. Ketika Remaja dan Pubertas Tiba. Yogyakarta: Hanggar Kreator. (2010).

[3] Survei Komisi Perlindungan Anak dan Kementerian Kesehata, Oktober 2013. https://www.kompasiana.com/rumahbelajar_persada/54f91d77a33311fc078b45f4/63-persen-remaja-di-indonesiamelakukan-seks-pra-nikah.

[4] BKKBN Online.. Separuh Remaja Kota Besar pernah Lakukan Seks Pranikah. http://www.bkkbn.go.id/Webs/index.php/berita/detail/2328. (2010).

[5] Lembaga Pemerhati Masyarakat. https://www.suarakalimantan.com/2016/12/hasil-survey-remaja-putribanjarmasin-65-tidak-perawan/. (2016).

[6] Bungin Burhan. Metodologi Penelitian Kualitatif. Jakarta : Raja Grafindo Persada. (2011).

[7] Yuandari, E \& Rahman, T.A. Metodologi Penelitian dan Statistik. Bogor: In Media. (2017).

[8] Ghule,M. Correlates of sexual behaviour of rural college youth in Maharashtra. India Eastern Journal Of Medicine 16 hal 122- 132. (2013).

[9] Nonsi, R. Faktor Yang Berhubungan Dengan Perilaku Seksual Pada Siswa SMA Negeri 5 Kendari Tahun 2015. Skripsi. Fakultas Kesehatan Masyarakat. UH0. (2015).

[10] Putri ,Nt. Analisis Faktor-Faktor Yang Berhubungan Dengan Perilaku Seksual Pranikah Siswa Di SMA Kartika Kota Kendari. Skripsi. Fakultas Kesehatan Masyarakat Universitas Halu Oleo Kendari. (2015)

[11] Rahmawati, Dewi, et al. Analisis Faktor-faktor yang berhubungan dengan perilaku seks pranikah mahasiswa kos-kosan dikelurahan Lalolara Tahun 2016. Jurnal Ilmiah Mahasiswa kesehatan Masyarakat Vol 2 No 5 Januari 2017. (2015).

[12] Banun, Sof.,et al. Faktor-faktor yang berhubungan dengan perilaku seksual pranikah pada mahasiswa semester V STIKES X Jakarta Timur 2012. Jurnal Ilmiah Kesehatan, vol 5(1); Jan 2013. (2013). 
[13] Rahmani,A.,Khoei,EM.,Banaem,LM.,Hajizadeh, E.,Hamdieh,M.,Montazeri,A. Development and psychometric evaluation of the Premarital Sexual Behavior Assessment Scale forYoung Women (PSAS-YW): an exploratory mixedmethod study. Reproductive-health-jurnal 2014,11:43. (2014). 